\title{
MALÉ ŠANCE A VALY V ČIERNOM. PRÍSPEVOK K POZNANIU PEVNOSTNÉHO SYSTÉMU JABLUNKOVSKÉHO PRIESMYKU
}

\author{
MAREK VOJTEČEK
}

\begin{abstract}
Abstrakt: Jablunkovský priesmyk predstavoval strategický bod v uhorsko-sliezskom pohraniči. Snahy o zabezpečenie tohto priestoru začali už v 16. storočí. Počas dvoch storoči tu bol vybudovaný rozsiahly systém samostatných vojenských opevnení rôznych kategórií. Malé šance a Valy v katastri obce Čierne predstavujú jeden z najrozsiahlejšich prvkov pevnostného systému Jablunkovského priesmyku. Systém opevneni tvoril valový násyp s priekopou, lokalizovaný na hrebeni vrchu Valy. Je doplnený troma kosoštvorcovými redutami a desiatimi redanmi. Samostatnú a najstaršiu jednotku pevnostného systému predstavuje hviezdicová pevnost' Malé šance na východnom okraji kopca. V posledných rokoch tu prebehlo niekol'ko výskumov, ktoré spresnili priebeh opevnenia a bližšie ozrejmili jeho konštrukčné prvky. V neposlednom rade sa získal rozsiahly súbor materiálnej kultúry, dokladajúci život pohraničnej vojenskej posádky v 17.-19. storočí.
\end{abstract}

Kl'účové slová: Jablunkovský priesmyk - Čierne - opevnenia-novovek.

Malé šance and Valy Fortifications at Čierne. Contribution to the information about the fortification system of the Jablunkov Pass

\begin{abstract}
The Jablunkov Pass (Jablunkovský priesmyk) presented a strategic point on the Hungarian-Silesian border. Efforts to secure this area go back to the 16th century. An extensive system of military fortifications of different categories was constructed there in the course of two centuries. Malé sance and Valy in the cadastral zone of the Cierne village are among the most prominent parts of the Jablunkov Pass fortification system. It consisted of a rampart with a ditch located on the crest of the Valy hill, and was supplemented with three diamond-shaped redoubts and ten redans. The Malé šance stronghold of a star-shaped ground plan on the eastern side of the hill was an independent and also the oldest feature of the fortification system. In recent years it has been subject to research that specified the course of the fortification and its construction elements. The research produced, among other things, a large series of material culture items shedding light on the everyday life of frontier garrisons in the 17th-19th centuries.
\end{abstract}

Key words: Jablunkov Pass - Čierne - fortifications - modern age.

\section{Úvod}

Jablunkovský priesmyk sa rozprestiera na rozhraní Moravsko-sliezskych a Slovenských Beskýd v nadmorskej výške 551-605 m n. m. a predstavuje významné miesto prechodu tohto horského pásma. Už od stredovekého obdobia tadial'to prechádzal dôležitý dopravný koridor spájajúci oblasti severozápadného Slovenska, českého a pol’ského Sliezska. Snahy o vojenské zabezpečenie tejto oblasti však sledujeme až od polovice 16. storočia zo strany Těšínskeho kniežatstva. V tomto období boli vybudované Staré šance vo Svrčinovci v bezprostrednej blízkosti dial'kovej cesty. Z roku 1578 pochádza správa o opravách na tejto pevnosti (Krůl 2013, 61). Do konca 18. storočia, v čase najväčšieho rozmachu, v širšom okolí priesmyku na sliezsko-uhorsko-pol'skej hranici evidujeme objekty v osemnástich lokalitách, s centrálnym bodom Vel'ké šance v Mostoch u Jablunkova (Krůl 2010a, 12). Impulzom pre vybudovanie systému opevnení bola turecká hrozba a snaha o zamedzenie prípadného postupu nepriatel'ských vojsk. Stála vojenská posádka v jablunkovskom priestore zohrala vel'kú úlohu počas tridsat'ročnej vojny, protihabsburských stavovských povstaní, sliezskych vojen o rakúske dedičstvo a sedemročnej vojny. V priebehu 19. storočia vzhl'adom na nové bojové postupy jednotlivé objekty strácali na význame a postupne zanikli. Do dnešných dní sa relikty v teréne zachovali v ôsmich polohách (Vel'ké šance v Mostoch u Jablunkova, Staré šance vo Svrčinovci, Malé šance a Valy v Čiernom, reduty v Mostoch - Doline, Bukovci - v Sušu, Čadci-Megoňkách, redany v Bukovci - na Kempe a na Dílku). Jedným zo základných a najviac zachovaných prvkov pevnostného systému Jablunkovského priesmyku sú Malé šance a Valy v Čiernom, ktoré sú predmetom tohto príspevku. 


\section{Lokalizácia systému opevnení}

Obec Čierne sa nachádza v severnej časti Kysúc v blízkosti súčasného trojštátneho bodu hranice Slovenskej republiky, Českej republiky a Pol'ska (obr. 1). Zachovaný pevnostný systém je lokalizovaný na tiahlom kopci Valy nad sútokom potokov Čadečka a Čierňanka. Kopec, výrazne pretiahnutý v osi východzápad, sa rozprestiera severovýchodne od intravilánu obce v nadmorskej výške 570-600 m, v dížke ca $1500 \mathrm{~m}$. Začína nepravidelným redanom na západnej strane kopca. Ten plynule prechádza do nízkeho spojovacieho valu, členeného minimálne desiatimi trojuholníkovými redanmi, prebiehajúceho medzi tromi kosoštvorcovými redutami (Reduty 1-3) v strednej časti kopca. Na východnej strane je tento fortifikačný systém ukončený hviezdicovou Redutou 4, v písomných a kartografických prameňoch označovanou ako Malé šance (Kleine Schantz/Schantzen).

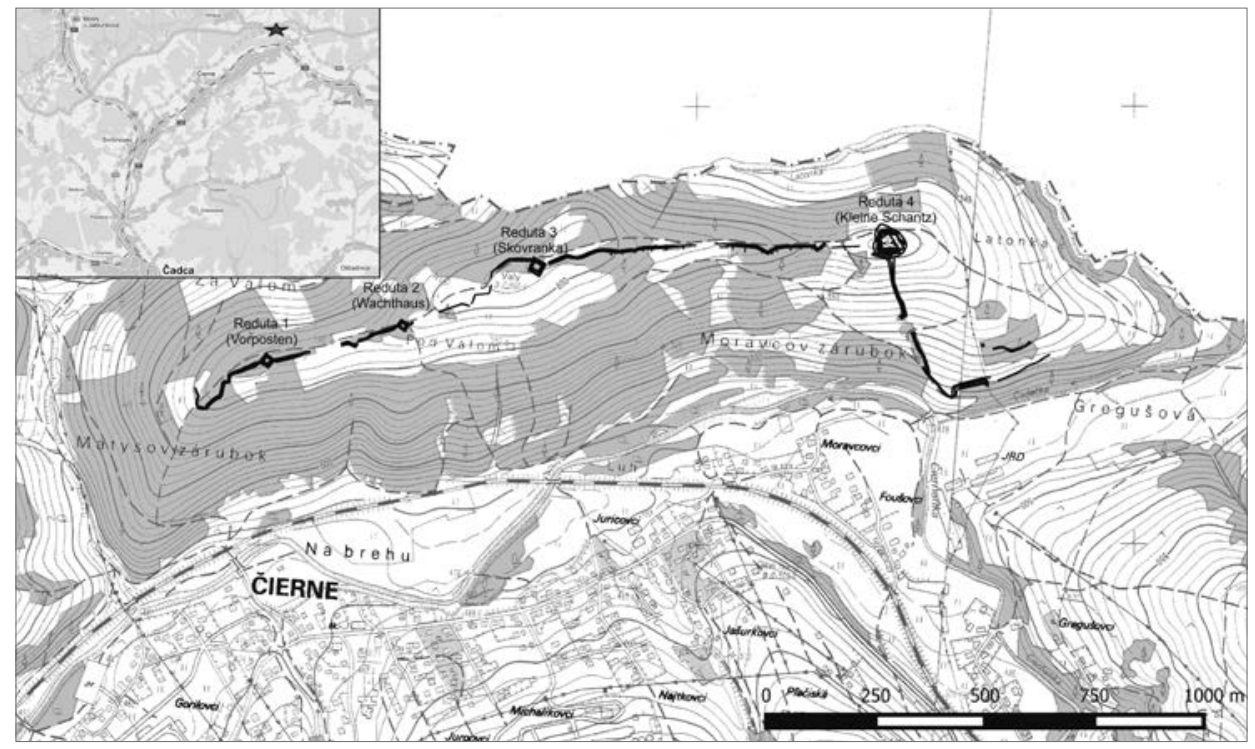

Obr. 1. Zachované prvky novovekého pevnostného systému v katastri obce Čierne. Plán M. Bartík a M. Vojteček. Abb. 1. Erhaltene Elemente des neuzeitlichen Befestigungssystems im Kataster der Gemeinde Čierne. Planskizze M. Bartík und M. Vojteček.

\section{Historický náčrt}

Pravdepodobný vznik pevnostného systému v katastri obce Čierne sa kladie do roku 1644, k rozšíreniu opevnenia dochádza v roku 1664 . V druhej polovici 17. storočia tvorila systém opevnenia na vrchu Valy hviezdicová zemná pevnost', prepojená s dvoma redutami súvislým zemným valom s palisádou. Správa Kristiána Marienbergera z roku 1678 hovorí, že pevnost' Malé šance tvoril „iba štvorhranný palisádový plot, bez priekopy a predprsne, vnútri sa nachádzalo šest' barakov, na 800 krokov nebola žiadna voda, pekárska pec ani miesto na uskladnenie municie a proviantu“. V roku 1683 sa už hovorí o opravách priekopy a predprsne, postavený je nový barak a opravené sú stojace objekty (Krůl 2012a, 148, 149). V 70-tych rokoch 18. storočia bola podl'a kartografických prameňov hviezdicová pevnost' spojená zemným valom s viacerými redanmi a štyrmi redutami (Krůl 2010, 210). Opevnenia v Čiernom, podobne ako celý pevnostný systém Jablunkovského priesmyku, strácali význam a postupne zanikli v priebehu 19. storočia. Systém opevnení je s rôznymi modifikáciami a schématickými prvkami vyobrazený na viacerých mapách zo 17.-19. storočia (Krůl-Nováková 2005). Najlepšie známe vyobrazenie sa nachádza na variantoch máp z roku 1772, kde sú jednotlivé prvky pomenované: Vorposten, Vachthaus, Skowranka, Kleine Schantz (obr. 2). 


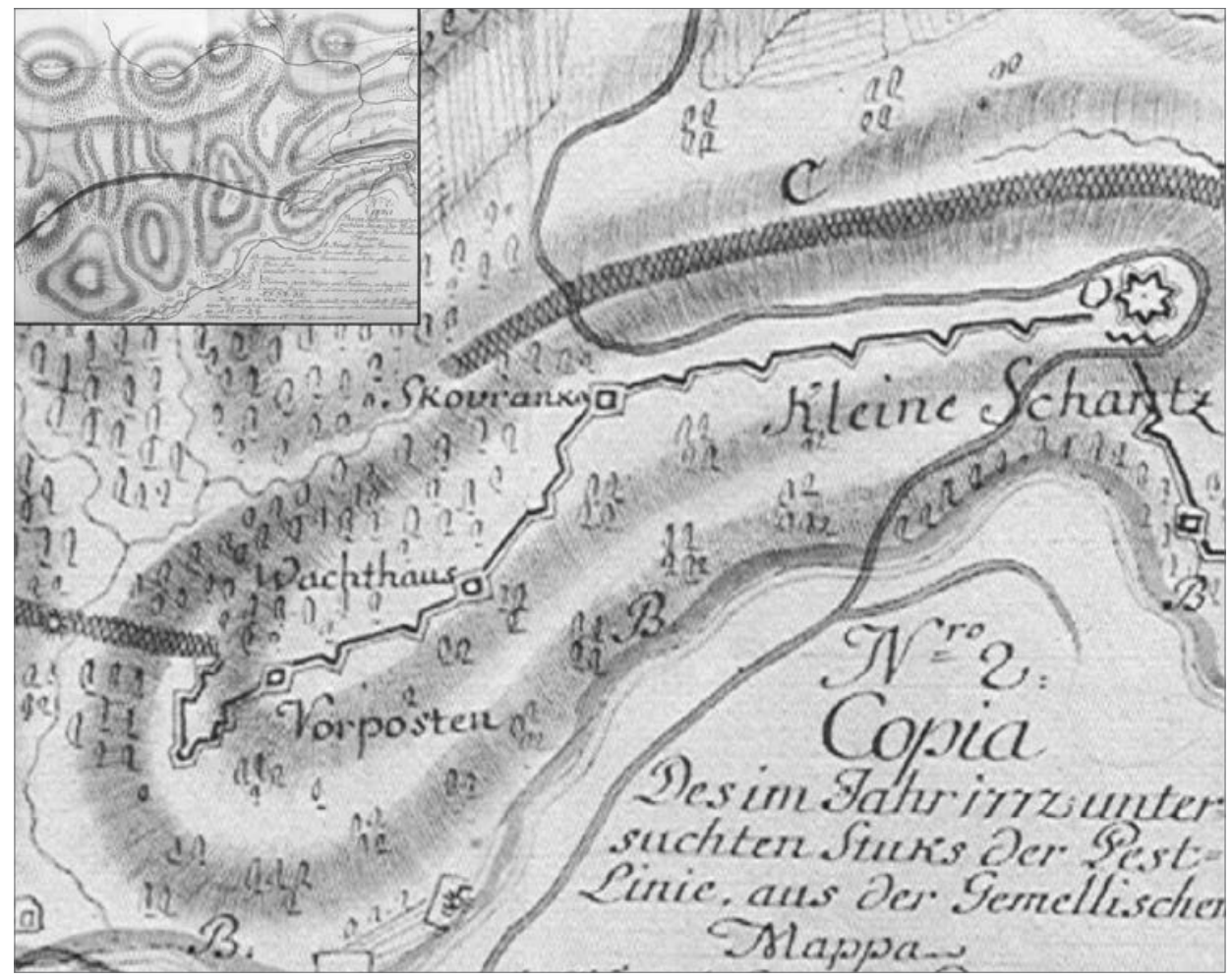

Obr. 2. Pevnostný systém Valy a Malé šance na mape z roku 1772.

Abb. 2. Befestigungssystem Valy (Wälle) und Kleine Schantzen auf einer Karte aus dem Jahr 1772.

\section{História archeologického bádania}

História archeologického bádania Valov a Malých šancí v Čiernom je, pravdupovediac, skromná. Súvisí to s ich okrajovou lokalizáciou v pohraničí severozápadného Slovenska, rovnako s ich „mladým“ datovaním, v minulosti menej atraktívnym pre bádatel’ov. Prvé archeologické prieskumy súvisia s aktivitami bádatel’ov Kysuckého múzea v Čadci. V osemdesiatych rokoch tu robil drobné prieskumné práce Ondrej Šedo (1981, 282). Drobné sondážne práce v areáli hviezdicovej pevnosti Malé šance realizovala v roku 1993 Marcela Ďurišová $(1995,36)$, ktorá konštatovala vnútri opevnenej plochy stopy po zástavbe. Za zmienku stoja aj prieskumy členov Českej archeologickej společnosti, ktorí sa v tomto priestore pohybovali v roku 2005 (ŠtěpánekTichánek 2005). Ich aktivita bola do istej miery sporná, nakol'ko výkopové práce autorov okrem etických zásad hrubým spôsobom porušili platné zákonné normy týkajúce sa ochrany kultúrneho dedičstva. Treba dodat', že v celej dížke línie opevnenia na kopci Valy sme počas prieskumov evidovali stopy po nelegálnych výkopoch a vyhl’adávaní nálezov detektorom kovov.

\section{Aktivity Archeologického ústavu SAV}

Opätovný záujem o toto územie súvisel s prieskumnými prácami Archeologického ústavu SAV v rokoch 2006 a 2007 v rámci projektovania dokumentácie pre stavebné povolenie dial'nice D3 Svrčinovec - Skalité. Prieskumy doložili stopy osídlenia v siedmich polohách v rámci trasy dial'nice a došlo k akémusi znovuobjaveniu Valov, ktoré doposial' neboli evidované v dokumentácii Archeologického ústavu SAV (Bednár 2007). Pre určenie rozsahu opevnení a ich možného ohrozenia sa vyhotovilo základné polohopisné zameranie systému. V tomto období 
prebehlo viacero stretnutí kompetentných orgánov ohl'adom odklonu trasy dial'nice z priestoru Valov, výsledkom ktorých bola menšia korekcia v prospech pamiatky, zapracovaná do projektovej dokumentácie. Po „znovuobjavení“ najvýznamnejších prvkov pevnostného systému Jablunkovského priesmyku na našom území sa vytvoril priestor pre viaceré projekty cezhraničnej spolupráce, ked’že sme zistili, že problematike sa intenzívne venuje Múzeum Těšínska v Českom Těšíne. Prvé spoločné prieskumy boli realizované v rámci projektu Vyšehradského fondu, ktorého nositel’om bola Regionálna rozvojová agentúra Kysuce: Šance - Valy: Common heritage. V spolupráci Archeologického ústavu SAV v Nitre a Múzea Těšínska v Českom Těšíne prebehla v roku 2008 dokumentácia reliktov zachovaných v teréne na Kysuciach a pril’ahlej časti českého Sliezska. Podarilo sa zdokumentovat' a zamerat' zachované relikty v šiestich polohách, vrátane domerania Valov v Čiernom (Bednár-Poláková-Vojteček 2008; Bednár a kol. 2011).

\section{Výskum v roku 2011}

V roku 2011 prebiehali terénne aktivity súvisiace s projektom európskeho fondu regionálneho rozvoja „Šance Valy - spoločná história plná tajomstiev“, ktorého nositel’om je Združenie obcí Mikroregión Kysucký triangel. V spolupráci Archeologického ústavu SAV v Nitre s Kysuckým múzeom v Čadci bol realizovaný menší výskum v areáli hviezdicovej reduty Malé šance (Bednár-Majerčíková-Vojteček 2011; 2012). Druhú čast' projektu, archívny výskum, realizovalo Múzeum Těšínska v Českom Těšíne (Krůl 2012). Samotný archeologický výskum mal viacero ciel'ov. V prvom rade išlo o podrobné výškopisné a polohopisné zameranie opevnenia a následné

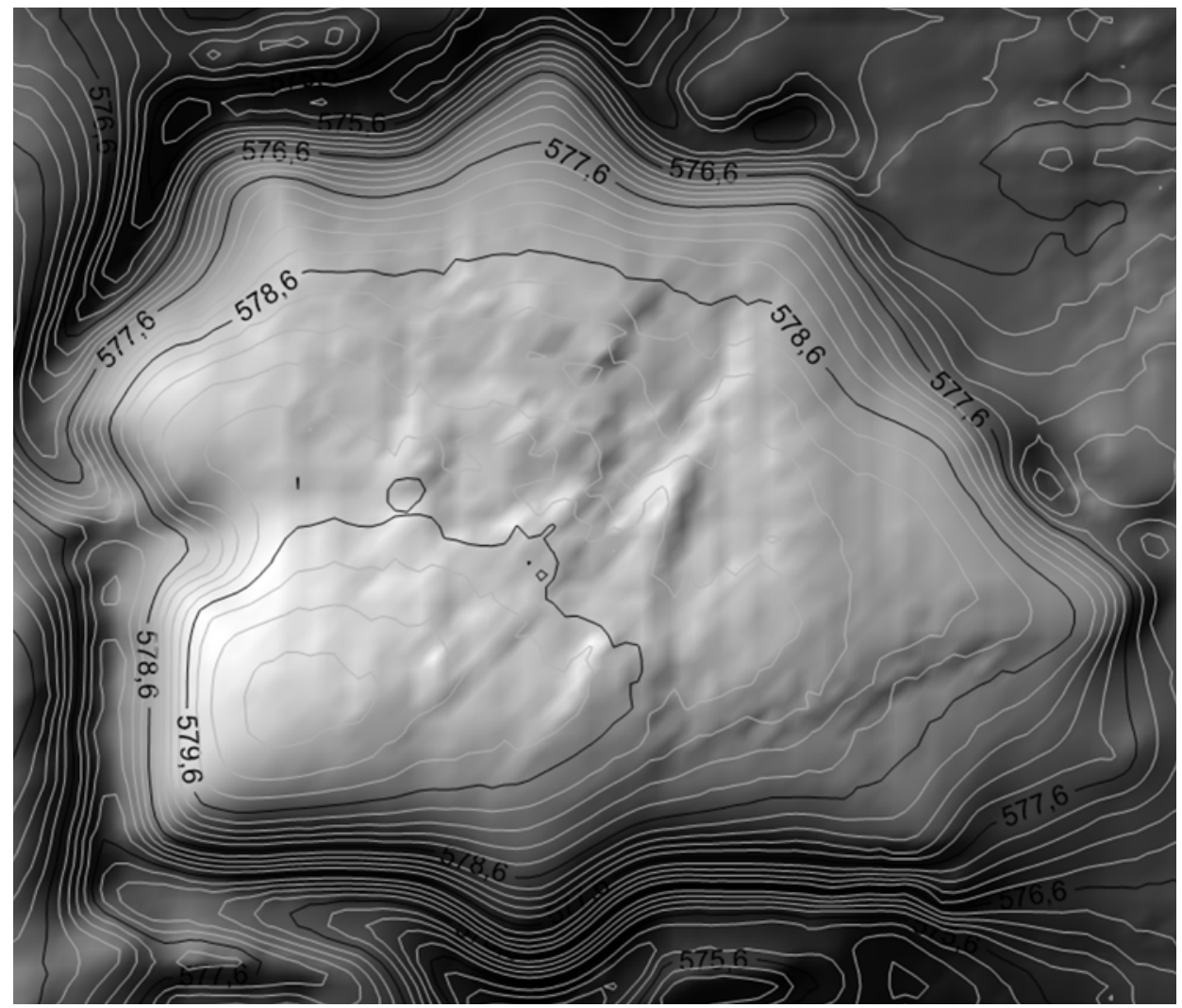

Obr. 3. Čierne - Malé šance. Terénny model hviezdicovej pevnosti. Plán M. Vojteček.

Abb. 3. Čierne - Kleine Schantzen. Geländemodell der Sternfestung. Planskizze M. Vojteček. 
vyhotovenie terénneho modelu reduty. $Z$ doterajších prieskumov totiž neexistovali žiadne terénne zamerania, $v$ dobových kartografických prameňoch je vyobrazená schematicky a nejasne. Táto fáza výskumu bola časovo najnáročnejšia, nakol’ko terén bol husto zarastený náletovou vegetáciou, ktorú bolo nutné odstránit'. Samotné meranie sa realizovalo GNSS prijímačom a totálnou stanicou. Zo zameraných bodov sme vyhotovili vrstevnicový model, ktorý bol podkladom pre 3D vizualizáciu terénu (obr. 3). Z nej je zrejmé, že pevnost' mala pôdorys nepravidelnej osemcípej hviezdice s rozmermi $57 \times 44 \mathrm{~m}$, ktorá bola pretiahnutá v osi východ-západ. Opevnenie bolo obohnané mohutnou priekopou, ktorá bola miestami hlboká až $3 \mathrm{~m}$ a výraznejším násypom na vonkajšej strane priekopy, ktorá bola zretel'ná predovšetkým z južnej strany. Vstup do areálu opevnenia sa nám podarilo identifikovat' od západnej strany, kde bola priekopa prerušená. Korešponduje to aj s údajmi na prvom vojenskom mapovaní, kde je v tomto priestore vyobrazené vyústenie spojovacieho valu. Podobnú terénnu depresiu indikujúcu vstup sme identifikovali pri východnom okraji pevnosti. V tomto prípade však ide pravdepodobne o neskoršie úpravy, ktoré vznikli po zániku opevnenia. Ďalším ciel’om bolo overenie terénnej situácie v areáli reduty pomocou sondážneho výskumu (obr. 4). Tomuto predchádzal podrobný prieskum detektorom kovov kvôli lokalizácií jednotlivých sond. V rámci areálu sme vykopali tri menšie sondy s rozmermi $1 \times 1 \mathrm{~m}$. Táto sondáž však nepriniesla požadované výsledky. Po prehíbení terénu o $20 \mathrm{~cm}$ sa vo všetkých troch prípadoch obnažila kompaktná kamenistá vrstva (obr. 5). Sporadické fragmenty keramiky a kachlíc sa nachádzali roztrúsené v povrchovej vrstve humusu. Vzhl'adom na pokročilé ročné obdobie, plánovaný rozsah výskumu a snahy minimalizovat’ negatívne zásahy do pamiatky sa sondy 1-3 nerozširovali, neprehlbovali a skončili na úrovni povrchu kamenistej vrstvy.

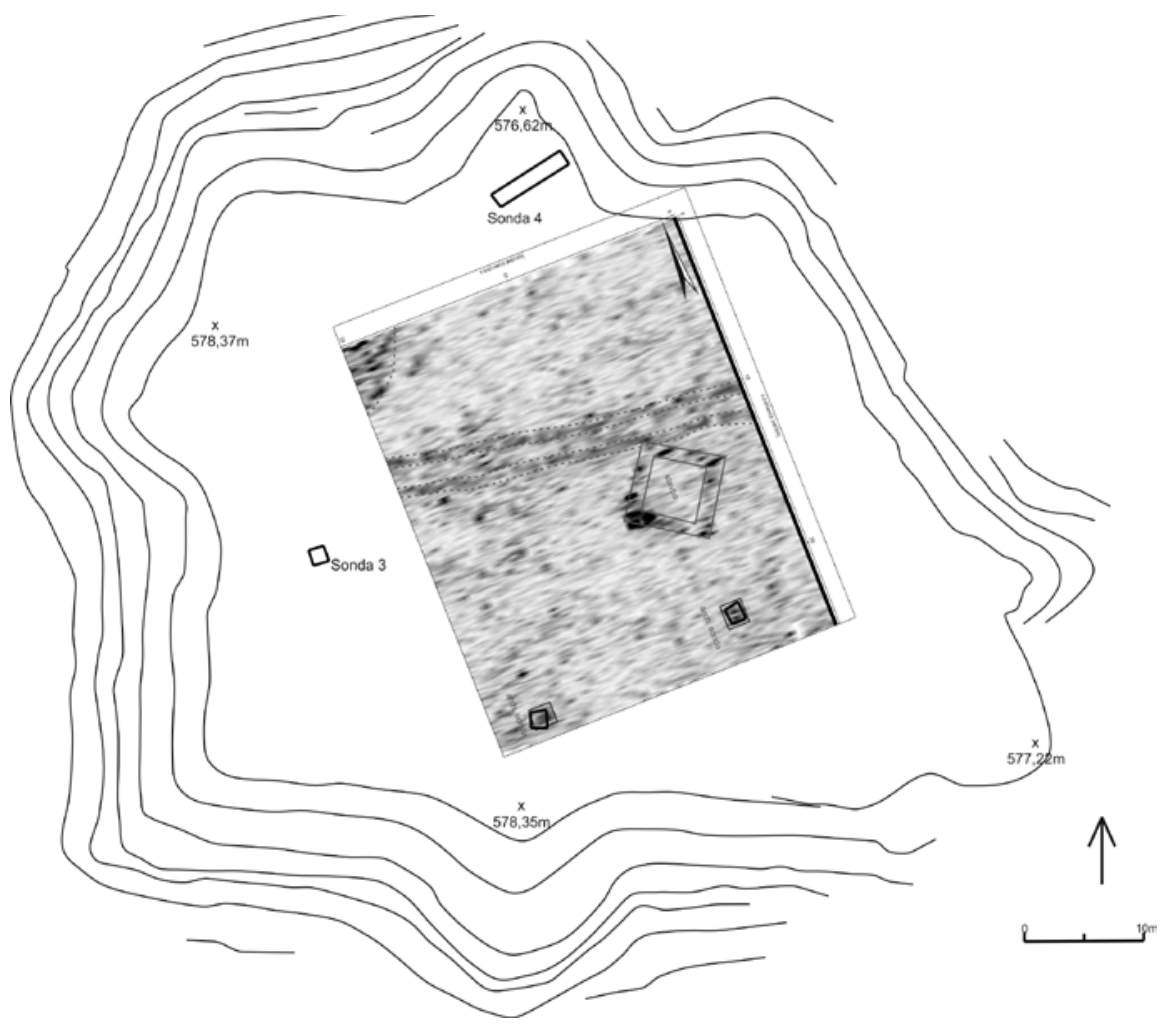

Obr. 4. Čierne - Malé šance. Plán hviezdicovej pevnosti s vyznačenými sondami z roku 2011 a georadarovým meraním z roku 2014. Plán M. Cheben a M. Vojteček.

Abb. 4. Čierne - Kleine Schantzen. Planskizze der Sternfestung mit eingezeichneten Sondierschnitten aus dem Jahr 2011 und Georadar-Messung aus dem Jahr 2014. Planskizze M. Cheben und M. Vojteček. 
Nakol'ko v sondách nebol zistený výraznejší archeologický materiál, štvrtú sondu s rozmermi $5 \times 1 \mathrm{~m}$ sme umiestnili v severnej časti reduty, v priestore hviezdicového výbežku. Prerezávala miernu terénnu depresiu a bola orientovaná v osi severovýchod-juhozápad, kolmo na zemný násyp opevnenia. Sonda mala ozrejmit' prípadné konštrukčné prvky opevnenia a interpretovat' funkciu depresie. Samotný terén sme znižovali po mechanických vrstvách až po úroveň podložia $\mathrm{v}$ hĺbke $1 \mathrm{~m}$ (obr. 6). V sonde sa pod vrstvou humusu (vrstva 1) zistila v západnej časti vrstva tmavohnedej kamenistej hliny s vel'kou prímesou kamenia, črepov kachlíc a keramických nádob (vrstva 3). Sporadicky sa vo vrstve objavili

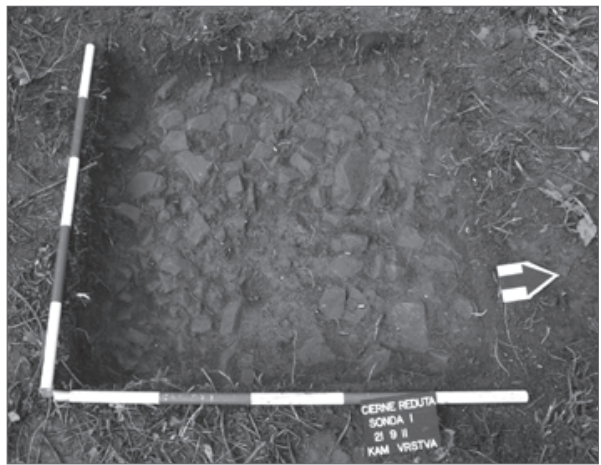

Obr. 5. Čierne - Malé šance. Kompaktná kamenistá vrstva v sonde 1. Foto M. Vojteček.

Abb. 5. Čierne - Kleine Schantzen. Kompakte Steinschicht in Sondierschnitt 1. Foto M. Vojteček.

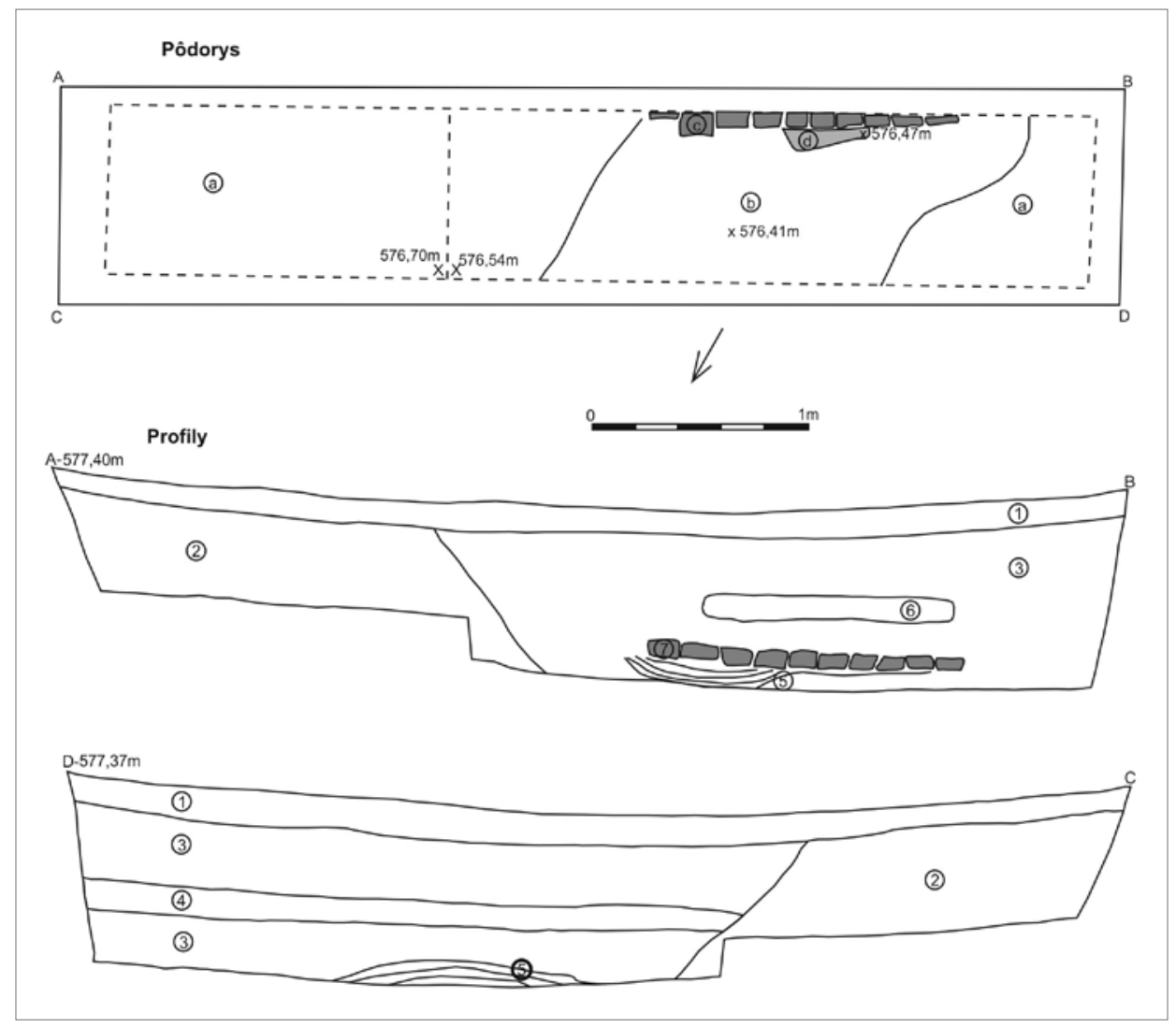

Obr. 6. Čierne - Malé šance. Sonda 4, pôdorys a profily. Legenda: a - žltá ílová zemina; b - čierna uhlíková vrstva; c - tehly; d-drevo; 1 - čierna humusová vrstva; 2 -žltá ílová vrstva, premiešaná s kameňmi; 3 - tmavohnedá hlinitá vrstva, premiešaná s kameňmi, črepmi a kachlicami; 4. vrstva deštruovanej keramiky a kachlíc; 5 -vrstvy popola; 6 - žltá ílová vrstva; 7 - tehly. Kresba M. Vojteček.

Abb. 6. Čierne - Kleine Schantzen. Sondierschnitt 4, Grundriss und Profile. Legende: a - gelbes Lehmerdreich; b - schwarze Holzkohleschicht; c - Ziegel; d - Holz; 1 - schwarze Humusschicht; 2 - gelbe Lehmschicht, vermischt mit Steinen; 3 - dunkelgelbe Lehmschicht, vermischt mit Steinen, Scherben und Kacheln; 4. Schicht mit zerstörter Keramik und Kacheln; 5 - Ascheschichten; 6 - gelbe Lehmschicht; 7 - Ziegeln. Zeichnung M. Vojteček. 
„planírky“ stavebnej sutiny (vrstva 4), žltého ílu (vrstva 6) a v spodnej časti popola (vrstva 5). Na úrovni nivelety 576,50-576,40 m n. m. sa pri južnej stene odkryl múr z nasucho kladených tehál, ležiaci na vrstve s vel'kou prímesou popola (obr. 7). Vel'ké množstvo uhlíkov a popola obsahovala aj okolitá vrstva. Iná situácia bola vo východnej časti sondy, kde sa zistila kompaktná homogénna vrstva žltej ílovitej hliny s vel'kou prímesou kamenia (vrstva 2). Vrstva bola stratigraficky staršia ako vrstvy 3-7. Zistenú situáciu môžeme interpretovat’ nasledovne. Vrstva 2 pravdepodobne predstavuje pozostatok zemného násypu opevnenia. Rozsah sondy bol malý a nevylučujeme, že opevnenie mohlo byt' na vnútornej strane spevnené. Vrstvy 3-6 predstavujú antropogénne sedimenty. Napriek tomu, že zlé terénne podmienky neumožnili podrobnejšie členenie vrstvy 3 , situácia naznačuje, že jej genéza prebiehala pravdepodobne vo viacerých fázach. Interpretácia tehlovej konštrukcie torzovite zistenej pod južnou stenou sondy naznačuje, že ide o základ vykurovacieho telesa. Uhlíková vrstva vymedzuje predpecný priestor a vznikla pri bežnej obsluhe vykurovacieho zariadenia.

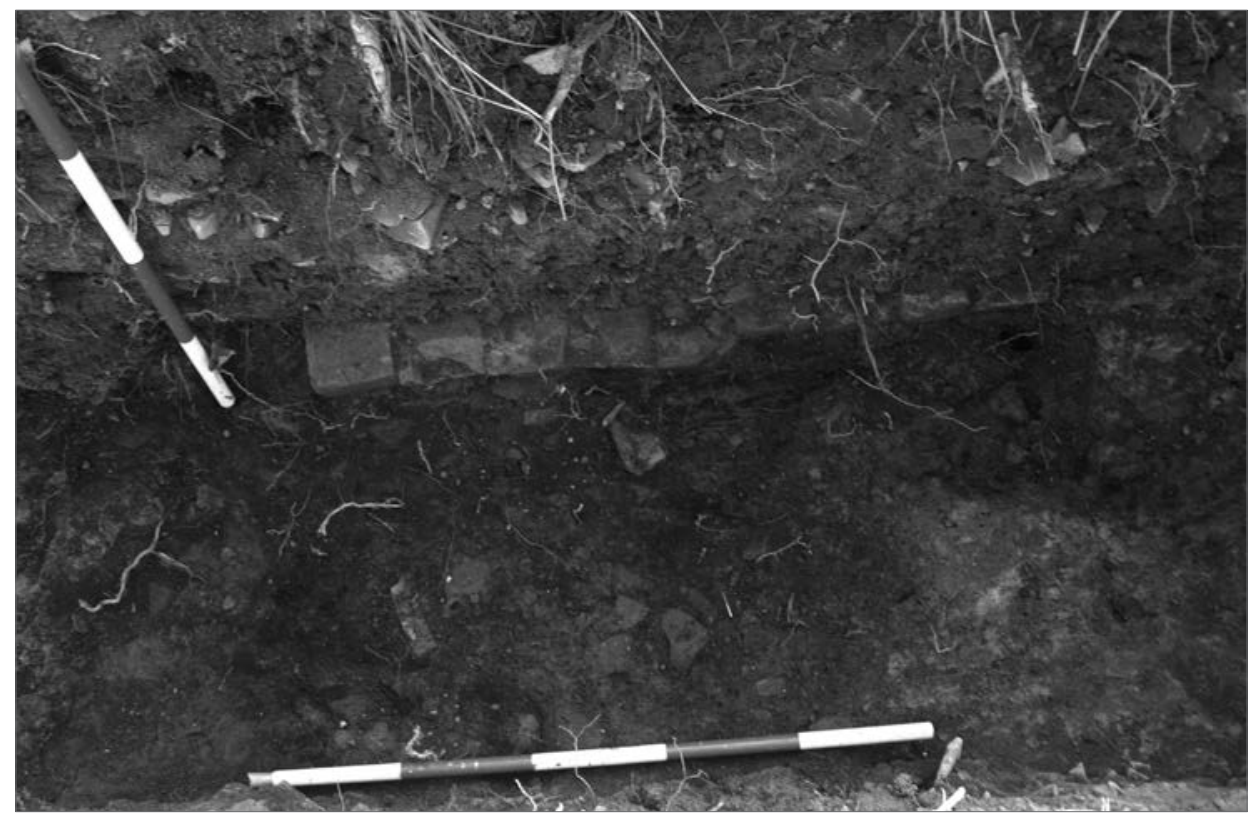

Obr. 7. Čierne - Malé šance. Tehlový múrik zachytený pri južnom profile sondy 4. Foto M. Vojteček.

Abb. 7. Čierne - Kleine Schantzen. Am Südprofil von Sondierschnitt 4 entdeckte Ziegelsteinmauer. Foto M. Vojteček.

\section{Výskum v roku 2014}

Nateraz posledné a najväčšie aktivity prebiehali v roku 2014 v rámci výstavby dial'nice D3 Svrčinovec - Skalité, na ktorú bola nadviazaná séria záchranných archeologických výskumov (Vojteček-Nemergut-Gábor 2015). Ciel’om výskumu v Čiernom bolo podrobné terénne zdokumentovanie súčasného stavu zachovania Valov a Malých šancí, identifikácia konštrukčných prvkov a spresnenie jej datovania v úsekoch, ktoré budú výstavbou dial'nice zničené. Kontroverzná, viackrát upravovaná trasa dial’nice mala „zlikvidovat““ 400 m priebehu opevnenia Valov vo východnej časti a južnú čast’ vonkajšieho násypu hviezdicovej pevnosti. V rámci výskumu sme mali možnost' testovat' rôzne metodické postupy. Nedeštruktívnu zložku výskumu predstavovalo podrobné geodeticko-topografické meranie nadzemných reliktov. Druhú čast' nedeštruktívnej zložky výskumu tvoril geofyzikálny prieskum vybraných dostupných plôch. Tento sa realizoval prostredníctvom georadaru a magnetometra. Deštruktívna zložka archeologického výskumu pozostávala z odkryvu terénnych situácií zemným strojom a ručným odkryvom. Prostredníctvom 
zemného stroja prebiehala sondáž a plošný odkryv v bezprostrednom okolí valového systému a na plochách, kde sa valy nezachovali, pričom ich priebeh tu bol predpokladaný. Ručný odkryv sa sústredil na jednotlivé zachované relikty. Išlo predovšetkým o rezy valom a priekopou v celej dížke opevnenia (23 rezov) a plošnú sondáž zemného násypu južne od hviezdicovej pevnosti Malé šance (9 sond). Aj napriek tomu, že archeologický výskum mal záchranný charakter a bol vykonávaný v časovom strese, podarilo sa získat' celý rad nových poznatkov.

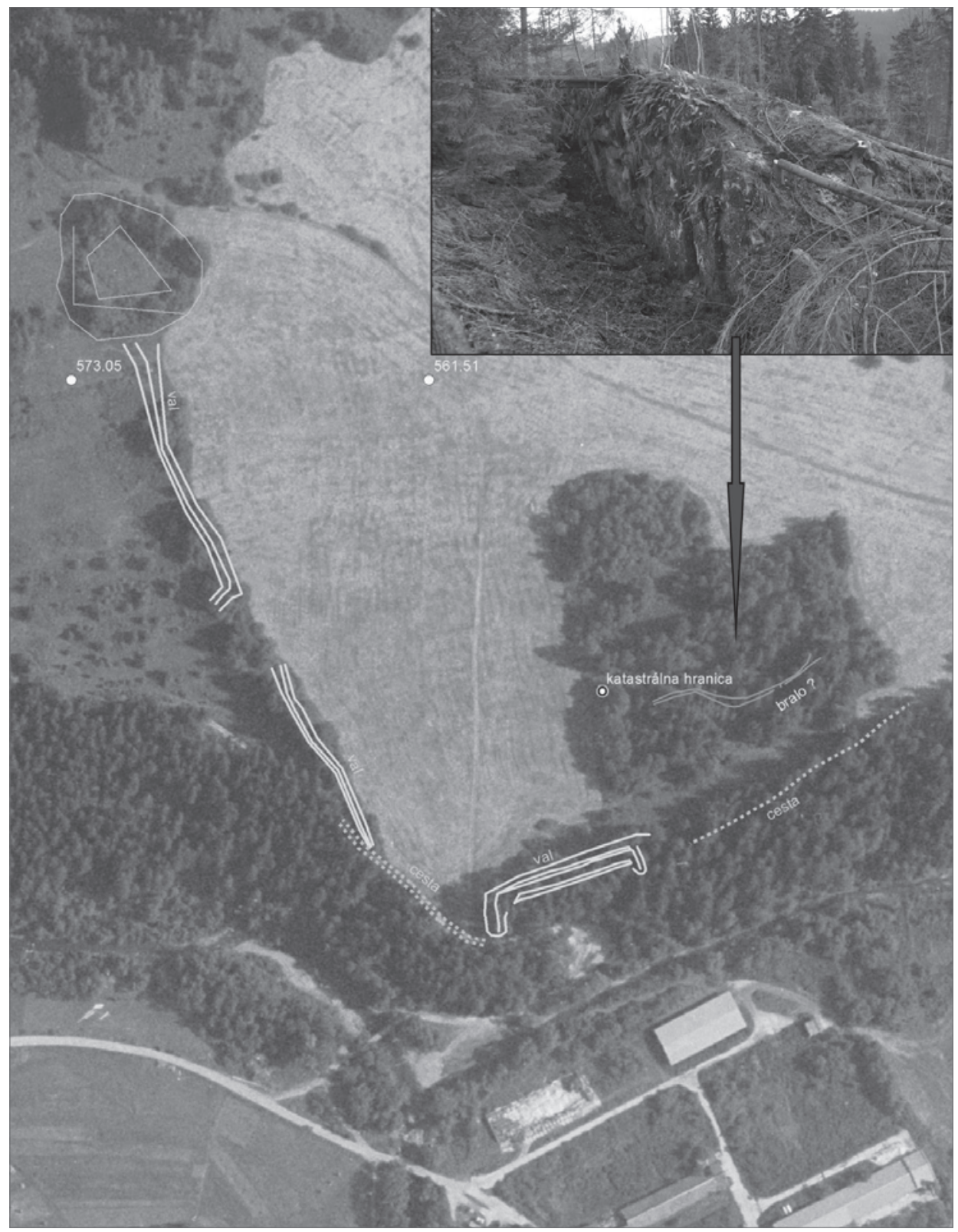

Obr. 8. Čierne - Malé šance. Zameranie novoobjavených prvkov pevnostného systému južne a juhovýchodne od pevnosti. Plán M. Bartík.

Abb. 8. Čierne - Kleine Schantzen. Vermessung der neuentdeckten Elemente des Befestigungssystems südlich und südöstlich von der Festung. Planskizze M. Bartík. 
Vyhotovila sa podrobná geodeticko-topografická dokumentácia úsekov pevnostného systému, ktoré výstavba dial'nice nenávratne zničí. Geodetické zameranie nadzemných terénnych reliktov tvorilo podklad pre vyhotovenie vrstevnicového terénneho modelu časti valového opevnenia dotknutej stavbou. Podrobným prieskumom sa podarilo zdokumentovat' d'alší priebeh opevnenia na strmom svahu v priestore južne a východne od Malých šancí. Terénna konfigurácia reliktov naznačuje existenciu d’alšej kosoštvorcovej reduty. Takýto priebeh je rovnako zretel'ný na liste (Collone XIII, Sectio II) Prvého vojenského mapovania. Ďalej sa dokumentovalo umelo zasekané skalné bralo, obranný prvok cca 350 m juhovýchodne od hviezdicovej pevnosti (obr. 8).

$\mathrm{Na}$ miestach mimo zalesneného terénu, kde neboli relikty valov zretel'né, sa realizovala plošná skrývka ornice zemnými mechanizmami s následným ručným dočistením plôch (obr. 9). Takýmto spôsobom sa podarilo zachytit' priebeh priekopy, ktorej výplň tvorila čierna spálená zemina, premiešaná s množstvom kameňov. Z toho je zrejmé, že val prebiehal až po západný okraj hviezdicovej pevnosti Malé šance. Rovnako v centrálnej časti systému, kde neboli zachované nadzemné časti, sa plošným odkryvom medzi Redutami 2 a 3 zachytil priebeh priekopy s dvomi trojuholníkovými redanmi. Existuje viacero podrobných mapových diel zobrazujúcich rôznu podobu pevnostného systému. Pri porovnaní so stavom zisteným v teréne je najvernejší obraz vyobrazený na mape z roku 1772, na ktorej sú zachované aj názvy jednotlivých redút (obr. 2).

V rámci deštruktívnej časti archeologického výskumu sme sa zamerali predovšetkým na spresnenie konštrukčných prvkov pevnostného systému (valu, priekopy, hviezdicovej pevnosti Malé šance). Sondážny výskum valového opevnenia bol realizovaný prostredníctvom 23 rezov, ktoré boli rovnomerne rozložené v úseku $450 \mathrm{~m}$ ohrozeného valu. Tieto mali šírku $1 \mathrm{~m}$ a dížku v závislosti od terénnej dispozície reliktov. Na základe situácie zistenej na profiloch rezov je zrejmé, že val bol navŕšený z jednoduchého zemného násypu a dosahoval výšku $40-110 \mathrm{~cm}$, v závislosti od stavu zachovania reliktov. Nevýrazná priekopa prebiehala paralelne južne od línie spojovacieho valu. Vo viacerých rezoch boli zistené tenké spálené vrstvičky (požiarové horizonty) v povrchových vrstvách. Pravdepodobne súviseli s vypal'ovaním porastu po opustení opevnenia, ktoré prebieha do dnešných dní. V jednom prípade (rez 3; obr. 10) boli zistené viacnásobné prepálené vrstvy, nad ktorými bol valový násyp opravovaný. Tieto požiarové vrstvy súviseli s vojenskou aktivitou v priebehu fungovania opevnenia. Palisádu na temene valu,

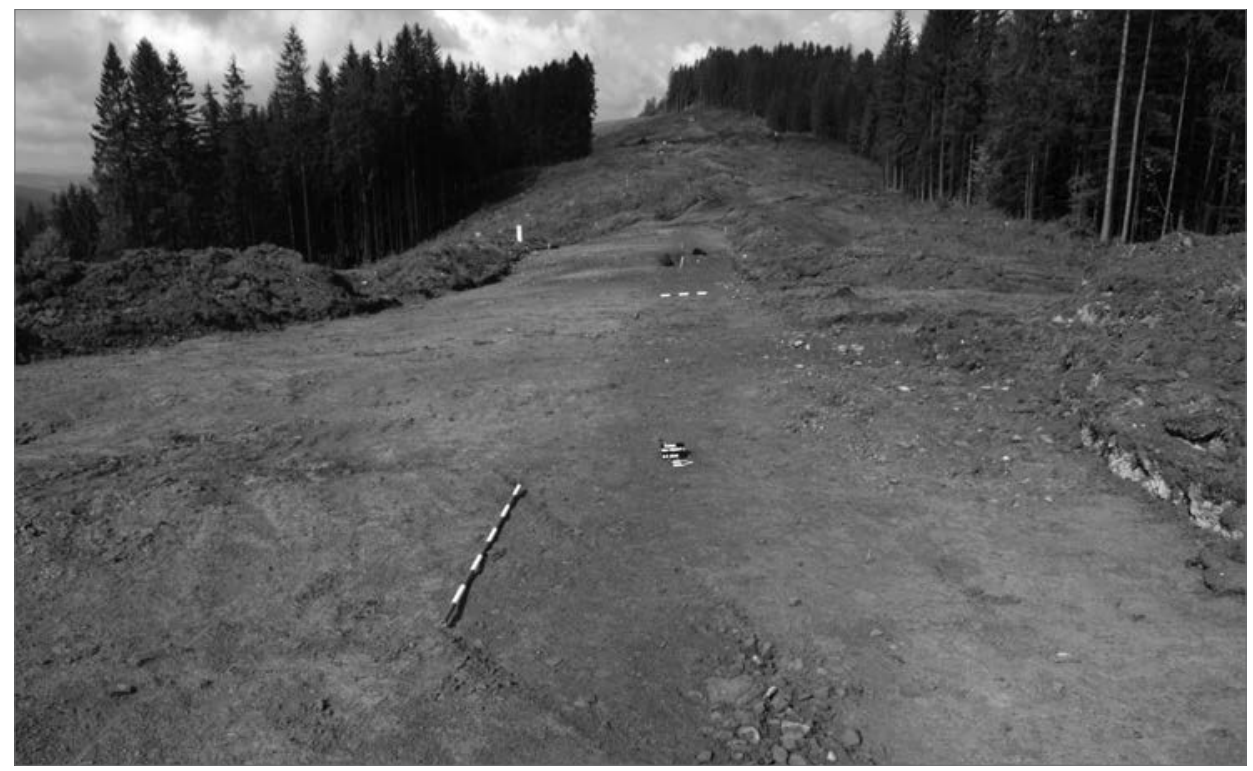

Obr. 9. Čierne - Valy. Priebeh zasypanej priekopy. Foto M. Vojteček.

Abb. 9. Čierne - Valy. Verlauf des zugeschütteten Grabens. Foto M. Vojteček. 
ktorú spomínajú viacerí autori pri tomto type opevnenia, sa nepodarilo presvedčivo preukázat'. To s najväčšou pravdepodobnost'ou súvisí s tým, že vrchná čast' násypu so stopami po palisáde bola eróznou činnostou odstránená.

V areáli hviezdicovej pevnosti Malé šance bol terénny výskum realizovaný iba v miestach dotknutých stavebnou činnostou (obr. 11). Tá zasahovala do priestoru zemného násypu na vonkajšej strane priekopy, južne od telesa reduty. Plošné odkrývanie valu v rámci deviatich sond priblížilo konštrukčné detaily tohto fortifikačného prvku. Zemný násyp bol najlepšie zachytený v sondách 3 a 4, kde dosahoval výšku 150-200 cm (obr. 12). Práve v tejto časti línia trvalého záberu stavby zasiahla najväčší úsek zemného násypu. Nálezy fragmentov keramiky a kachlíc boli vo viacerých sektoroch zistené v celom telese násypu, nie iba v povrchových vrstvách, resp. pod úrovňou násypu. Z toho jednoznačne vyplýva, že zemina získaná na jeho navŕšenie musela byt' „kontaminovaná“ materiálom z už stojacej fortifikácie. O tom, že prvá fáza opevnenia ešte nebola obohnaná priekopou a valovým násypom, svedčia v konečnom dôsledku aj písomné pramene. V správe inžiniera Kristiána Marienbergera zo 14. marca 1678 sa nachádza opis pevnosti,

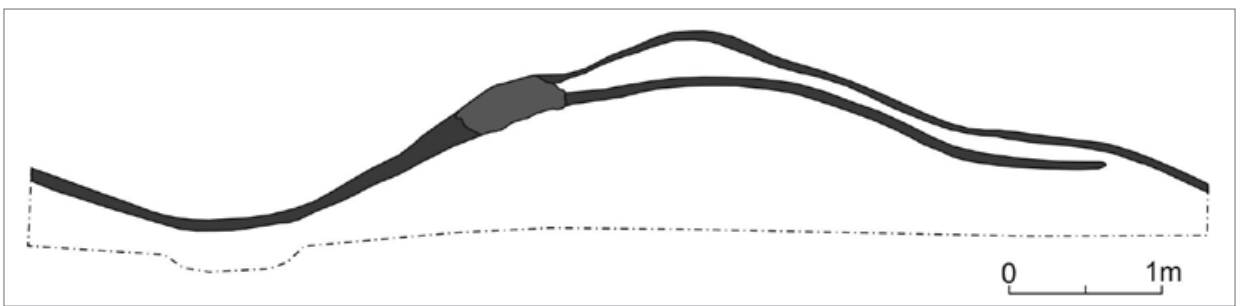

Obr. 10. Čierne - Valy. Profil spojovacieho valu a priekopy v reze 3. Kresba M. Vojteček.

Abb. 10. Čierne - Valy. Profil des Verbindungswalles und des Grabens in Schnitt 3. Zeichnung M. Vojteček.

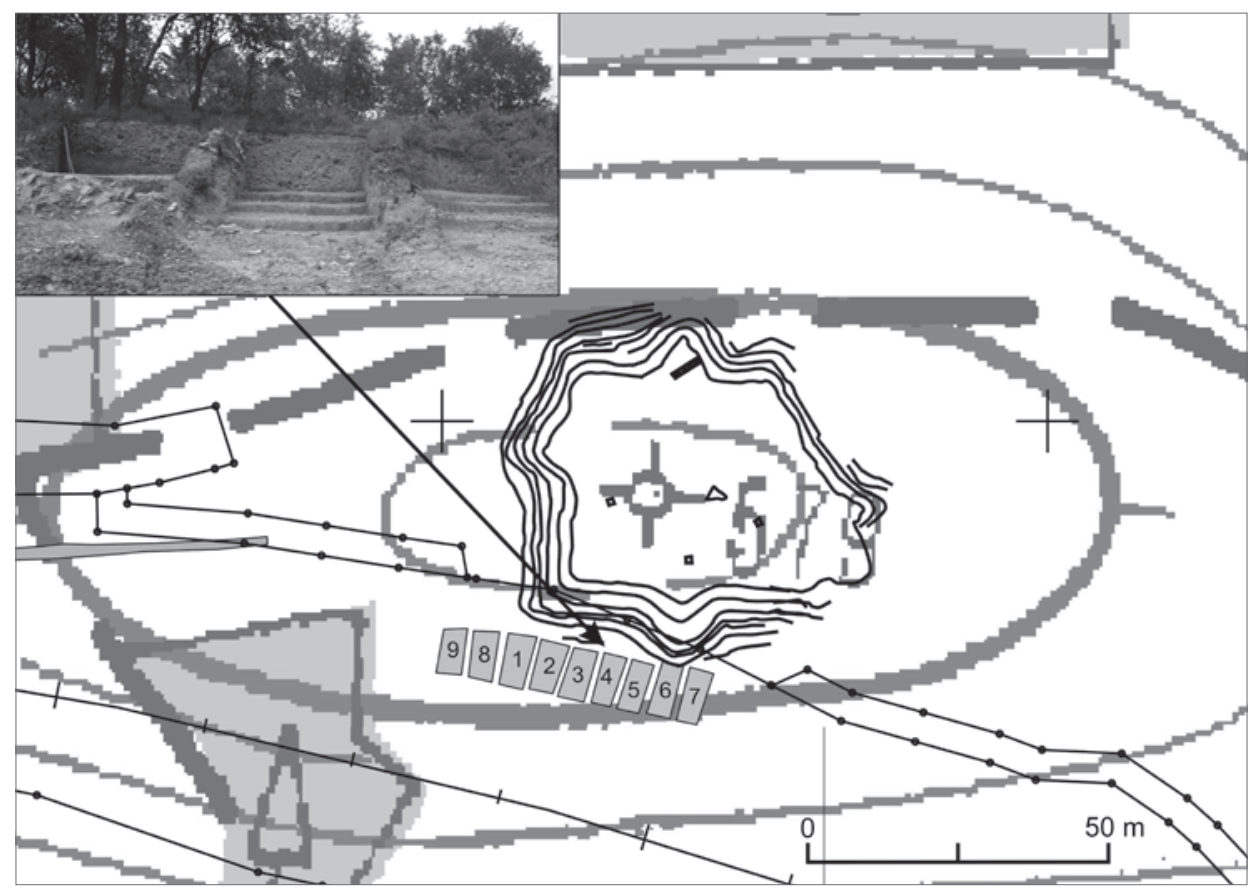

Obr. 11. Čierne - Malé šance. Sondážny výskum zemného násypu predprsne južne od pevnosti. Foto a plán M. Vojteček. Abb. 11. Čierne - Kleine Schantzen. Sondierungsgrabung der Brustwehraufschüttung südlich der Festung. Foto und Planskizze M. Vojteček. 


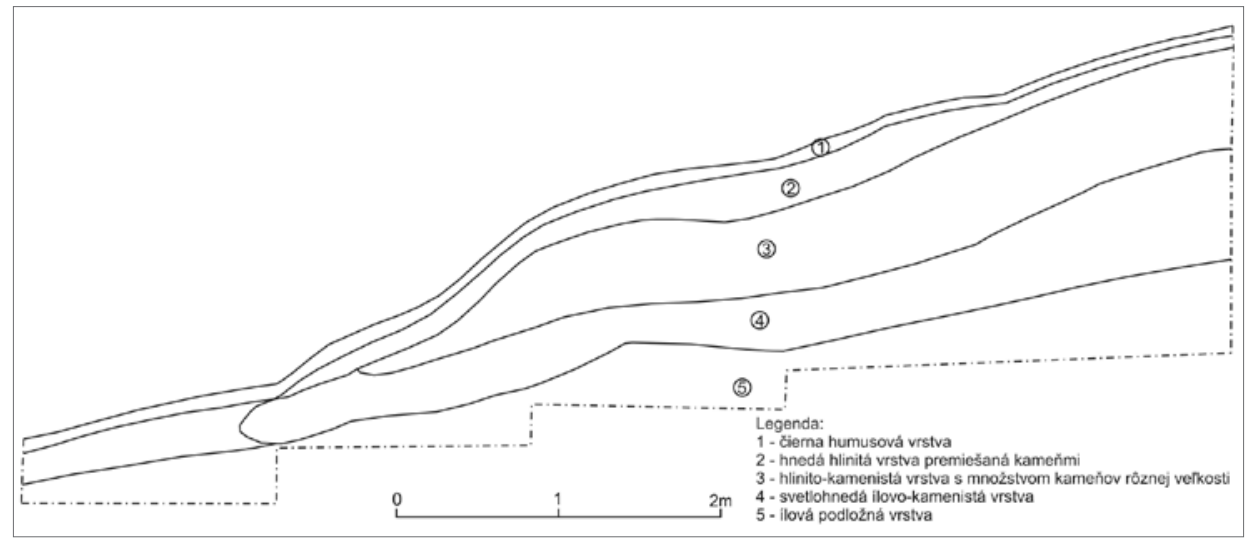

Obr. 12. Čierne - Malé šance. Sonda 4, západný profil. Kresba M. Vojteček.

Abb. 12. Čierne - Kleine Schantzen. Sondierschnitt 4, Westprofil. Zeichnung M. Vojteček.

ktorú tvorí „iba štvorhranný palisádový plot bez priekopy a predprsne. Vnútri sa nachádzalo 6 barakov, na 800 krokov nebola žiadna voda, pekárska pec ani miesto pre uskladnenie municie a proviantu" (Krůl 2012a, 148). Vo viacerých sondách sa zachytila vrstva kameňov rôznej vel'kosti, ktorá sa koncentrovala predovšetkým pri päte valu. Tieto kamenné deštrukcie pravdepodobne predstavovali jednoduché spevnenie vonkajšieho plášt’a valu. Previazanie kamennej vrstvy maltou nebolo potvrdené.

\section{Geofyzikálne merania v pevnosti Malé šance}

Geofyzikálne merania sa realizovali na viacerých miestach v rámci trasy dial’nice prostredníctvom georadaru a magnetometra (Cheben 2014; 2015, 135). Na prieskum magnetometrickou metódou sa použil magnetometer Sensys DLM-98 s 5-kanálovým systémom s vertikálnymi sondami. Využitie magnetometra v hornatých kysuckých podmienkach však neprinieslo požadované výsledky. Vyhodnotené horizontálne mapy vykazovali viacero magnetických anomálií, ktoré však boli spôsobené recentnými železnými predmetmi. Podobne to bolo aj s georadarom, kde sa podarilo zachytit' iba nezretel'né odrazy priekopy v priestore západne od hviezdicovej pevnosti. Georadar sme však využili aj pri meraní v interiéri hviezdicovej pevnosti s ciel'om overit' prítomnost' stavieb. Na meranie bol použitý georadar RAMAC-X-3M s $500 \mathrm{MHz}$ tieňovou anténou s hustotou merania $0,05 \mathrm{~m}$ v rozostupe profilov $0,5 \mathrm{~m}$. Híbka merania dosahovala $3 \mathrm{~m}$. V centrálnej časti opevnenia sa podarilo zachytit' pôdorys štvorcovej stavby s rozmermi $5 \times 5 \mathrm{~m}$ v híbke $60-140 \mathrm{~cm}$, ktorého murivá majú šírku 40-50 cm. Anomália sa nachádza v blízkosti staršieho nelegálneho výkopu, takže až seriózny terénny odkryv ukáže stav zachovania základov budovy (obr. 4).

\section{Materiálna kultúra}

Počas archeologických výskumov v rokoch 2011 (Majerčíková 2012) a predovšetkým 2014 sa podarilo získat' relatívne vel'ké množstvo predmetov materiálnej kultúry. Absolútna väčšina archeologického materiálu bola získaná zo zemného násypu južne od Malých Šancí. Dominantnú zložku tvorili fragmenty kuchynského riadu a stavebnej keramiky, ktorú reprezentovali fragmenty kachlíc. Z keramických tvarov sa tu vyskytoval bežný kuchynský a stolový riad, ako sú flaše, taniere, misky. Získané komorovité kachlice s kvadratickou komorou a zaoblenými rohmi sa vyznačujú širokou škálou rôznorodých motívov (obr. 14). Prevažovala tapetová výzdoba so štylizovanými rastlinnými motívmi, úponkami a palmetami, doplnenými geometrickými motívmi. Ojedinele sa na kachliciach objavili architektonické motívy. Kachlice mali glazúrový povrch prevažne v škále zelených odtieňov, ojedinele sa vyskytovala hnedá glazúra. 

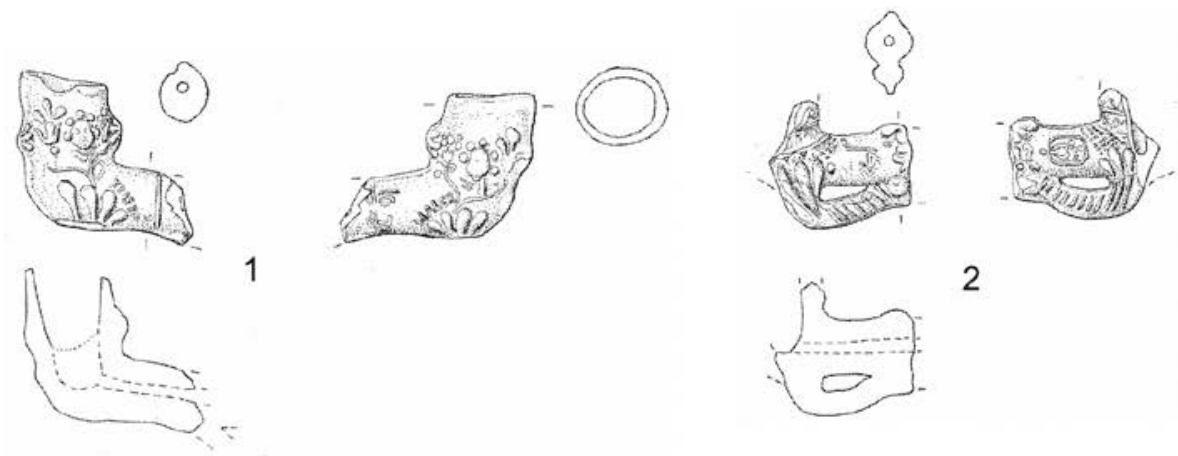

1

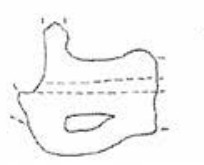

2
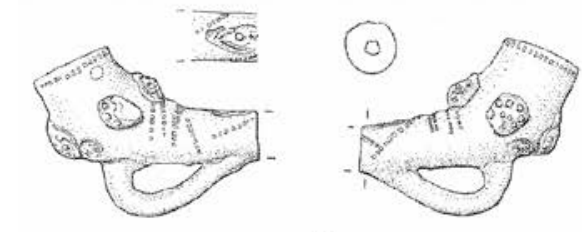

3
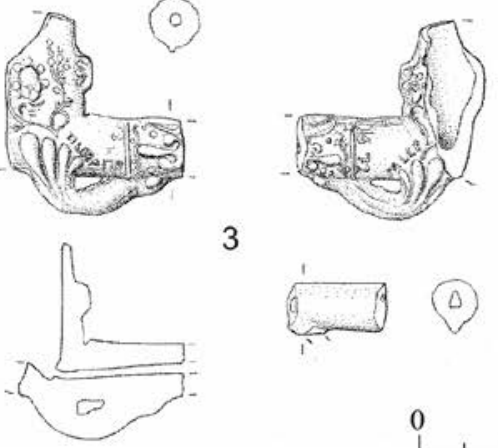

(D)
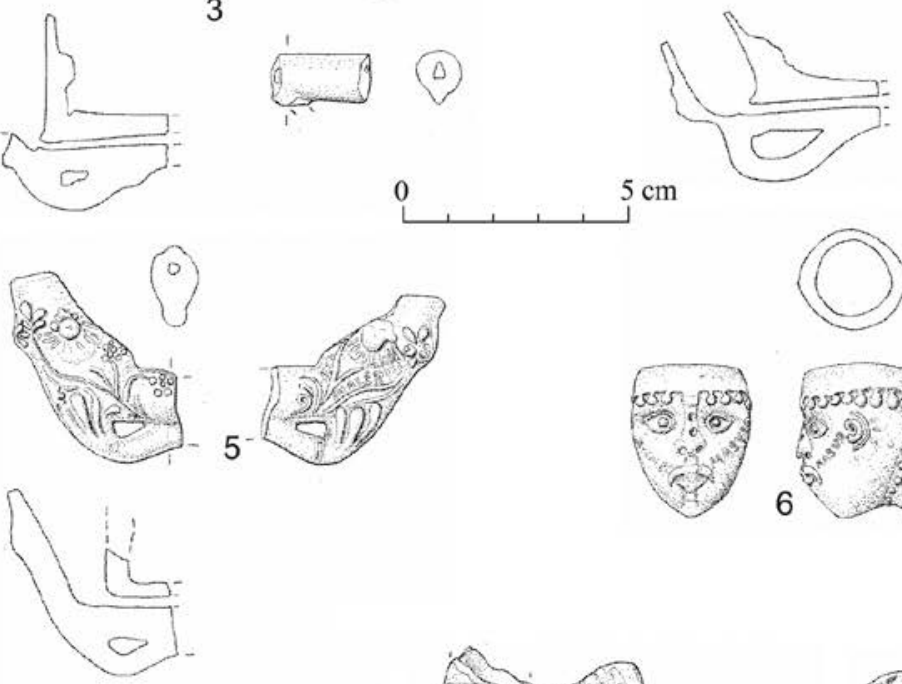

4
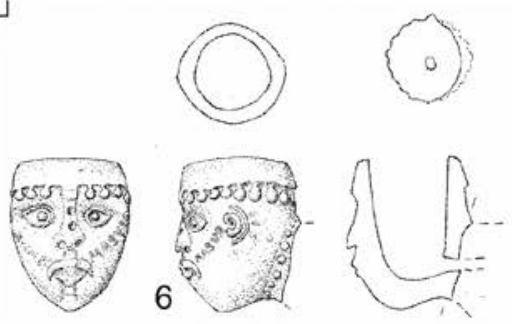

7
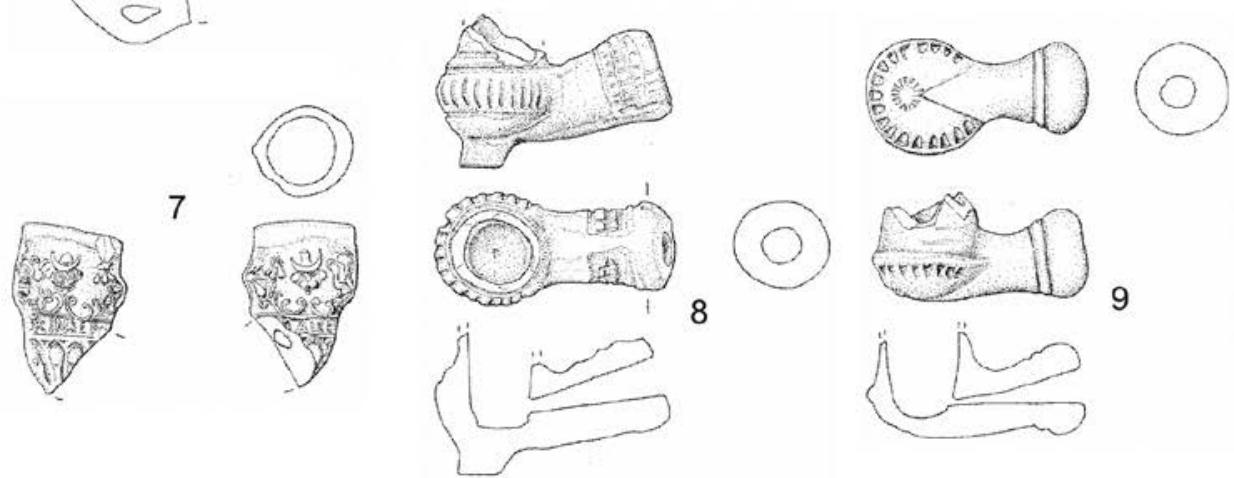

Obr. 13. Čierne - Malé šance. Nálezy jednodielnych a dvojdielnych hlinených fajok zo zemného násypu južne od pevnosti. Kresba J. Hritzová.

Abb. 13. Čierne - Kleine Schantzen. Funde von ein- und zweiteiligen Tonpfeifen aus der Erdaufschüttung südlich der Festung. Zeichnung J. Hritzová. 
Medzi predmety dokladajúce sociálnu a kultúrnu identitu vojenskej posádky Malých šancí patria fragmenty hlinených fajok. Pri plošnej sondáži v priestore zemného násypu južne od hviezdicovej pevnosti bolo objavených spolu 37 hlinených fajok, z ktorých je 24 jednodielnych a 13 fajok je dvojdielnych. Podla sprievodného materiálu, ktorý bol objavený v rovnakých vrstvách, je možné súbor datovat' do druhej polovice 17. až začiatku 18. storočia. Jednodielne fajky boli vyrobené z bielej kaolínovej hliny. Niektoré boli glazované zelenou glazúrou. Na fajkách sa nachádzali nápisy: KINSER MALER s chronogramom 1672 a MASUR na fajke s hlavičkou muža (obr. 13). Dvojdielne fajky boli taktiež glazované a hlina bola červenej alebo pieskovej farby. Glazúra, ktorá sa objavuje na fajkách, je bud' transparentná, hnedá, zelená a v jednom prípade modrá. Nálezy fajok dokladajú dôkaz o „fajčiarskej kultúre“ žoldnierov, ktorí pôsobili na Jablunkovskom priesmyku v čase jeho najintenzívnejšieho využívania na konci 17. storočia. Jednodielne fajky z Čierneho sú však rozhodne importy, pravdepodobne zo Sliezska alebo z Nemecka. Dvojdielne fajky sa vyrábali v Uhorsku pod vplyvom z juhu, z Osmanskej ríše. Koniec 17. storočia bol poznačený stavovskými povstaniami proti Habsburgovcom a poslednou etapou osmanskej expanzie.

Z d'alších predmetov tu boli objavené fragmenty kresacích kameňov, gombíkov a nášiviek uniforiem i niekol'ko skorodovaných kusov mincí. V jednom prípade sa podarilo identifikovat' strieborný 3-groš z roku 1622, razbu pol'ského král'a Žigmunda III. Datovanie razby korešponduje s obdobím predpokladaného vzniku pevnosti (1. polovice 17. storočia).
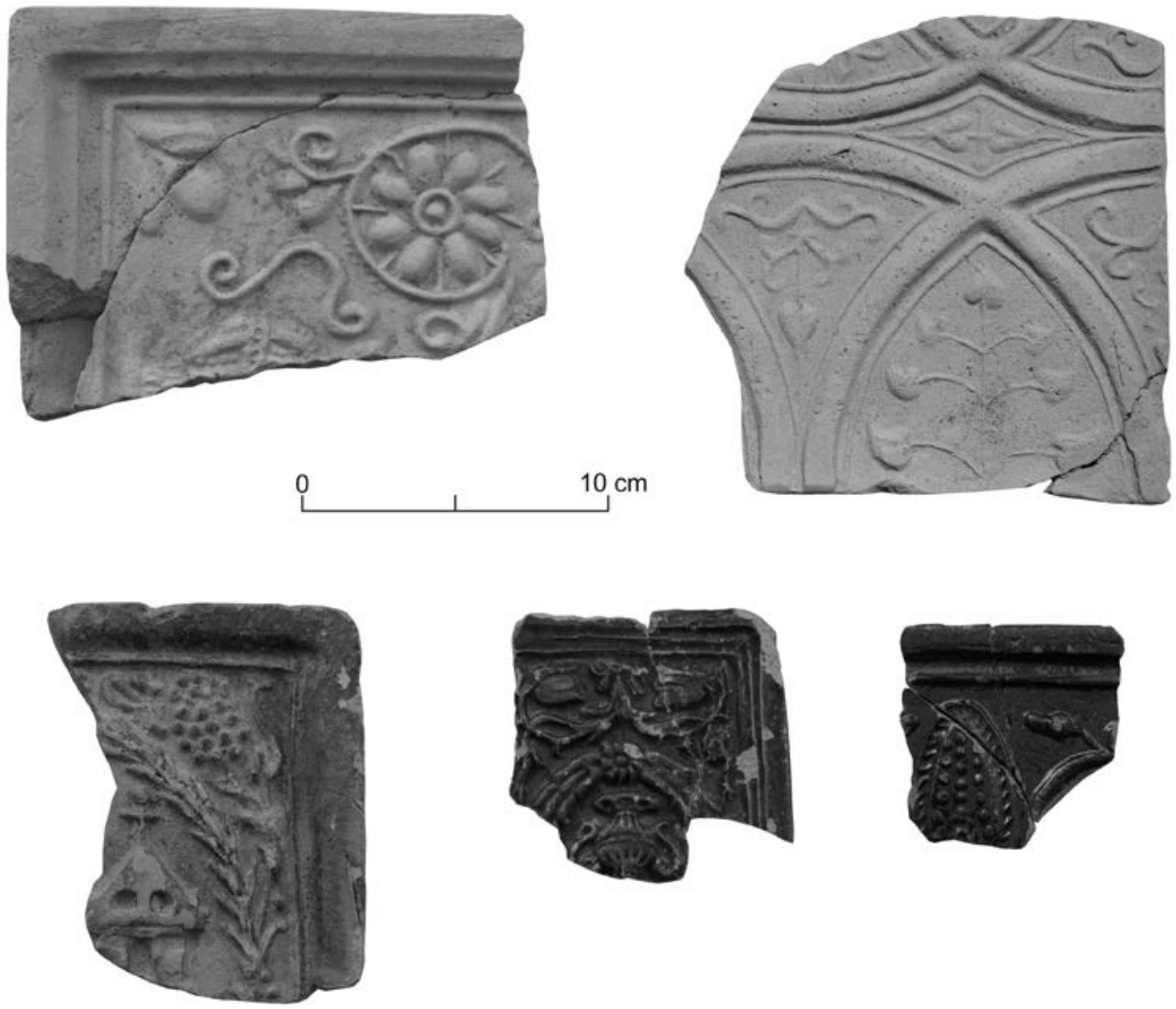

Obr. 14. Čierne - Malé šance. Nálezy kachlíc z pevnosti. Foto M. Vojteček.

Abb. 14. Čierne - Kleine Schantzen. An der Festung gemachte Kachelfunde. Foto M. Vojteček. 


\section{Záver}

Je na škodu veci, že Malé šance a Valy v Čiernom boli dlhú dobu na okraji odborného záujmu archeológov, pričom k ich „,znovuobjaveniu“ došlo až v súvislosti s plánovanou stavbou, ktorá spravila výrazný negatívny zásah do celistvosti pamiatky, pričom viac ako jednu tretinu zničila úplne. Stav vyobrazený na aktuálnych snímkach Google Earth však jasne ukazuje fakt, že okrem 450 m valov dotknutých výstavbou cesty je výrazne narušený aj celkový genius loci tohto miesta, najrozl'ahlejšej a jednej z najvýznamnejších pamiatok kysuckého regiónu. Aktivity, ktoré sme v tomto priestore vykonávali od roku 2007, aspoň čiastočne prispeli k poznaniu pevnostného systému Jablunkovského priesmyku v katastri obce Čierne a rovnako podnietili miestnu samosprávu k lepšiemu povedomiu a ochrane zvyšných častí tejto unikátnej pamiatky.

Príspevok vznikol v rámci grantu APVV-15-0330 Človek a krajina na Kysuciach a prilahlom Považí v stredoveku a na začiatku novoveku - Human and landscape in Kysuce and adjacent Považie region in middle ages and beginning of modern age.

\section{Literatúra}

BEDNÁR, P., 2007: Dial’nica D3, úsek Svrčinovec - Skalité, archeologické lokality na trase dial'nice - DSP. Nepublikovaná správa ulož. v dokumentácii AÚ SAV v Nitre.

BEDNÁR, P. a kol., 2011: Bednár, P.-Krůl, M.-Poláková, Z.-Vojteček, M.-Bartík, M., Pevnostný systém Jablunkovského priesmyku. In: AVANS 2008, 46-47. Nitra.

BEDNÁR, P.-MAJERČÍKOVÁ, D.-VOJTEČEK, M., 2011: Čierne - Valy, Reduta 4. Výskumná správa z archeologického výskumu. Nepublikovaná správa ulož. v dokumentácii AÚ SAV v Nitre.

- 2012: Výsledky archeologického výskumu novovekého opevnenia v Čiernom. In: Šance - Valy, spoločná história plná tajomstiev, 26-33. Čadca.

BEDNÁR, P.-POLÁKOVÁ, Z.-VOJTEČEK, M., 2008: Stav a perspektívy archeologického výskumu pevnostného systému Jablunkovského priesmyku. In: "Šance - Valy: common Heritage", 12-19. Čadca.

ĎURIŠOVÁ, M., 1995: Prieskum na Kysuciach. In: AVANS 1993, 36-37. Nitra.

CHEBEN, M., 2014: Čierne - D3, poloha: Valy, fortifikačný systém. Výskumná správa z geofyzikálneho prieskumu. Nepublikovaná správa ulož. v dokumentácii AÚ SAV v Nitre.

- 2015: Geofyzikálna prospekcia na Slovensku v rokoch 2010 až 2014, ŠZ AÚ SAV 57, 111-139.

KRŮL, M., 2010: Pevnostní stavitelství na příkladu fortifikací těšínského Slezska - Jablunkovské šance - Fortification architecture in the example of fortress in Těšín Silesia - Jablunkov fortification. In: Těšínsko v proměnách staletí. Sborník přednášek z let 2008-2009 k dějinám těšínského Slezska (Jež, R.-Pindur, D., edd.), 201-214. Český Těšín.

- 2010a: Stav výzkumu novověkých opevnění slezsko-uhersko-polské hranice. In: Polní opevnění od třicetileté války do roku 1945. Sborník Národního památkového ústavu, územního odborného pracoviště v Josefově, 6-18. Jaroměř-Josefov.

- 2012: Jablunkovské šance ve fondech Österreichisches Staatsarchiv ve Vídni. Zpráva o výsledku archivního výzkumu. In: Šance - Valy, spoločná história plná tajomstiev, 9-14. Čadca.

- 2012a: Posádka na Jablunkovských šancích. Příspěvek k poznání života v raně novověkém opevnění. In: Šlachta na Kysuciach a jej susedia - Šlechta na Kysucích a její sousedé (Pindur, D.-Turóci, M., edd.), 145-162. Čadca - Český Těšín - Žilina.

- 2013: Fortyfikacje górskie Przełęczy Jabłonkowskiej - Neuzeitliche Befestigungen am Jablunkapass. In: Twierdza srebrnogórska IV. Wojna siedmioletnia w Sudetach i nowożytne fortyfikacje górskie, 59-74. Wrocław.

KRŮL, M.-NOVÁKOVÁ, P., 2005: Jablunkovské šance. Český Těšín.

MAJERČÍKOVÁ, D., 2012: Archeologické nálezy zo Starých a Malých šancí na Kysuciach. In: Šance - Valy, spoločná história plná tajomstiev, 3-8. Čadca.

ŠEDO, O., 1981: Prieskum archeologických lokalít v okrese Čadca. In: AVANS 1980, 282-285. Nitra.

ŠTĚPÁNEK, J.-TICHÁNEK, J., 2005: Malé šance u Javořinky (Kleine Schantze). In: Archeologie Moravy a Slezska, 49-57. Kopřivnice - Hulín - Frýdek-Místek - Havírovov. 


\section{Zusammenfassung}

\section{Kleine Schantzen und Valy in Čierne. Ein Beitrag zum Festungssystem des Jablunkapasses}

Der Jablunkapass war ein strategischer Punkt im ungarisch-schlesischen Grenzgebiet und bildete im Mittelalter eine wichtige Verkehrsader. Bemühungen, diesen Raum militärisch zu sichern, wurden im Laufe des 16. Jahrhunderts seitens des Herzogtums Teschen unternommen. Binnen zwei Jahrhunderten wurde dort ein ausgedehntes System errichtet, das aus selbständigen militärischen Befestigungen verschiedener Kategorien bestand. Eines der ausgedehntesten und erhaltensten Elemente des Befestigungssystems des Jablunkapassses sind die im Kataster der Kischützer (Region Kysuce) Gemeinde Čierne gelegenen sog. Kleinen Schantzen und Valy. Das Befestigungssystem bestand aus einer einfachen, auf dem Kamm des Hügels Valy nördlich der Gemeinde lokalisierten Wallaufschüttung mit Graben. Es wird von drei Redouten und mindestens einem Dutzend Redans ergänzt. Eine selbständige und gleichzeitig die älteste Einheit des Befestigungssystems stellt die Sternfestung Kleine Schantzen am Ostrand des Hügels dar. Im Jahr 2008 wurde vom Archäologischen Institut der Akademie der Wissenschaften in Nitra zusammen mit dem Museum der Region Teschen in Český Tešín ein Projekt durchgeführt, das die Dokumentation des Befestigungssystems des Jablunkapasses beinhaltete. Im Rahmen des Projekts erfolgte auch eine grundlegende Lagevermessung des Redouten-, Redan- und Wallsystems in Čierne. Eine weitere Grabungsetappe erfolgte in den Herbstmonaten des Jahres 2011. Das Archäologische Institut der Akademie der Wissenschaften hat gemeinsam mit dem Kysuce Museum in Čadca an der sternförmigen Festung Kleine Schantzen eine Sondierungsgrabung durchgeführt. Die archäologische Grabung von 2014 wurde durch den Bau des Autobahnabschnitts D3 Svrčinovec - Skalité verursacht. Eine kontroverse, mehrfach abgeänderte Trassenführung hatte negative Einwirkungen auf den Verlauf von fast der Hälfte des Festungssystems zur Folge. Das Ausmaß des Baus umfasste die Erdaufschüttung südlich von der Festung Kleine Schantzen und $400 \mathrm{~m}$ des Verbindungswalls sowie die Redane im östlichen Teil des Wallsystems. Durch eine Kombination von zerstörungsfreier Untersuchung, Sondierschnitten und großflächigen Freilegungen ist es gelungen, den Verlauf der Befestigungsanlage zu präzisieren und seine Konstruktionselemente verständlicher zu machen. Nicht zuletzt wurde ein umfangreicher Fundkomplex an materieller Kultur gewonnen, vor allem Bau- und Gebrauchskeramik, Pfeifenfragmente, die das Leben der im 17.-19. Jahrhundert im Grenzgebiet stationierten Militärgarnisonen belegen.

Der vorliegende Beitrag entstand im Rahmen des Förderprojekts APVV-15-0330 Mensch und Landschaft in Kysuce und angrenzenden Považie Region im Mittelalter und der frühen Neuzeit - Human and landscape in Kysuce and adjacent Považie region in middle ages and beginning of modern age.

Mgr. Marek Vojteček, PhD., Archeologický ústav SAV, Akademická 2, SK 94901 Nitra, Slovenská republika, marek.vojtecek@savba.sk 
